\title{
Leaf Chlorophyll Content and Agronomic Performance of Bt and Non-Bt Soybean
}

\author{
Paulo Rogério Beltramin da Fonseca ${ }^{1}$, Marcos Gino Fernandes ${ }^{2}$, Wagner Justiniano ${ }^{2}$, \\ Leonardo Hiroito Cavada ${ }^{1} \&$ João Alfredo Neto da Silva ${ }^{1}$ \\ ${ }^{1}$ Faculdade de Ciências Agrárias, Programa de Pós-Graduação em Agronomia (Produção Vegetal), Universidade \\ Federal da Grande Dourados, Dourados/MS, Brazil \\ ${ }^{2}$ Faculdade de Ciências Biológicas e Ambientais, Programa de Pós-Graduação em Entomologia e Conservação \\ da Biodiversidade, UFGD. Universidade Federal da Grande Dourados, Dourados/MS, Brazil \\ Correspondence: Paulo Rogério Beltramin da Fonseca, Faculdade de Ciências Agrárias, Programa de \\ Pós-Graduação em Agronomia (Produção Vegetal), Universidade Federal da Grande Dourados, Dourados/MS, \\ Brazil. E-mail: prbeltramin@hotmail.com
}

Received: September 4, 2013 Accepted: September 24, 2013 Online Published: November 15, 2013

doi:10.5539/jas.v5n12p117 URL: http://dx.doi.org/10.5539/jas.v5n12p117

\begin{abstract}
The objective of this study was to evaluate the levels of chlorophyll and agronomic performance of $\mathrm{Bt}$ and non-Bt soybeans. For the evaluation we used the chlorophyll meter (SPAD-502), which was collected randomly in the upper third (TS), middle third (TM) and lower thirds (TI). Evaluations were performed at 7, 14, 21, 28, 35, 42, $49,56,63$, and 70 days after emergence (DAE). Used the randomized experimental design in a split plot design $(2 \times 3 \times 10)$ with four replicates for analysis of chlorophyll content and factorial $2 \times 2$ (two cultivars and two regions) with four replications for the factors of production. For the region of Dourados, the highest chlorophyll levels were presented to $42 \mathrm{DAE}$ for soybeans Bt and non-Bt, the TS and TI, for TM at $42 \mathrm{DAE}$ for soybeans Bt and non-Bt to $35 \mathrm{DAE}$. In Douradina the highest levels of chlorophyll were for soybean at $28 \mathrm{DAE} \mathrm{Bt}$ and non $\mathrm{Bt}$ at $49 \mathrm{DAE}$ in the lower third. For TM and TS cultivars Bt and non-Bt had higher chlorophyll content at 35 DAE. From the results obtained, it can be concluded that the Bt technology did not influence the chlorophyll content of soybean, the two cultivars showed similar levels, with higher concentrations in the middle third of the plants in the two regions studied. For agronomic attributes, plant height, first pod height, number of pods per plant and yield, Bt soybeans had higher values compared to non-Bt soybeans in two environmental studies.
\end{abstract}

Keywords: Glycine max L, chlorophyll, genetically modified organism, position the plant

\section{Introduction}

Soybean [Glycine $\max$ (L.) Merrill] is a major crop exotic Brazilian agribusiness, with great economic importance in grain exports and its derivatives, and has advantages such as higher yield potential and greater uniformity morphological and phenological, which facilitate crop management (Neves et al., 2013; Antunes et al., 2012).

The recommendation of specific genotypes for each environment, the stratification of a heterogeneous area into more homogeneous sub-regions and the identification of genotypes with wide adaptability and stability, the alternatives have been proposed to mitigate the effect of genotypes with environments (Pelúzio et al., 2010).

The introduction of a gene into the genome of a receptor is a complex change, depending on the gene itself into the host genome (Yin et al., 2004). Agronomic crops can be harmed after transformation with different genes.

Considering the data relating to food safety, environmental risks and efficiency in the production system, evaluated during the 50 years of use of Bacillus thuringiensis as biopesticide, one can consider that the Bt-plants is a tool that aids in the production system (Homrich et al., 2008). The main objectives in the generation of Genetically Modified (PGM), is to increase plant resistance to insects (Yuan \& Knauf, 1997; Yu et al., 2011; Dutra et al., 2012). With this, despite the great advances in technology Bt represents to world agriculture, their adoption in some regions may be affected positively or negatively, depending on the characteristics of each locality (Barros \& Degrande, 2012).

Thus soybean yield is defined by the interaction of the plant with the environment and management (Pereira et al., 2011), thus high yields are only obtained when such conditions are favorable, at all stages of crop growth. With 
this, studies on the energy efficiency of Bt plants by chlorophyll index is important ace new varieties and are key to explain the development and possibly the best performance.

The plant growth and adaptation to different environmental conditions are related to photosynthetic efficiency which, in turn, is associated, among other factors the concentration of chlorophyll. Several internal and external factors affecting the biosynthesis of chlorophyll, so their contents leaf can vary significantly. Among these factors, the light is essential to biosynthesis (Sousa et al., 2011). The chlorophyll is constantly being synthesized and destroyed (photo-oxidation) in the presence of light, but under higher light intensities greater degradation occurs and equilibrium is established at a lower concentration. Therefore, the shade leaves have higher chlorophyll concentration than the sun leaves (Kramer \& Kozlowski, 1979).

The standard method for determination of chlorophyll in the laboratory, yet easy, has drawbacks, since it results in destructive collection of plant material, being relatively long (Arnon, 1949). With the advent of portable meters, which use non-destructive optical principles, based on the absorbance and reflectance of light by leaves, the determination of chlorophylls became quick and easy and can be performed directly in the field (Richardson et al., 2002).

The pigment chlorophyll is responsible for capturing the light used in photosynthesis, they are essential in the conversion of light radiation into chemical energy in form of ATP and NADPH (Araujo et al., 2013).

Thus, chlorophyll is related to the photosynthetic efficiency, and consequently to its growth and adaptability to different environments. In the 90 was available equipment capable of generating quantities related to the contents of chlorophyll, the chlorophyll "Soil Plant Analysis Development" - SPAD-502 (Minolta, 1989). This instrument is portable and provides readings that can relate to the content of chlorophyll present in the leaf (Uddling et al., 2007; Guimarães et al., 1999).

The chlorophyll meter Minolta SPAD-502 has been used in the quantification of chlorophyll, characterized by speed, simplicity, and especially by enabling non-destructive evaluation of leaf tissue. The current model has been successfully used to diagnose the state of nitrogen crops such as corn, potato, wheat, among others (Argenta et al., 2001).

The chlorophyll content in the leaf is influenced by several biotic and abiotic factors, is directly related to the potential photosynthetic activity of plants (Taiz \& Zeiger, 2008). So its quantification is important in the study of cultural practices and management in order to increase the photosynthetic potential and increased production (Fonseca et al., 2012).

There is demand for research in Brazilian conditions in order to evaluate the agronomic performance of $\mathrm{Bt}$ and non-Bt soybeans, moreover, there is still lack of scientific information about the behavior of this technology within the different regions of the country this context, this study aimed evaluate the contents of chlorophyll and agronomic performance of $\mathrm{Bt}$ and non-Bt soybeans in two regions under field conditions.

\section{Material and Methods}

The experiment was conducted under field conditions in two experimental areas located at Farm Rincão Porã, the geographic coordinates $22^{\circ} 14^{\prime} 25^{\prime \prime} \mathrm{S}, 54^{\circ} 42^{\prime} 60.7^{\prime \prime} \mathrm{W}$ and altitude of $403 \mathrm{~m}$ in the town of Dourados and Fazenda good Luck in the geographical coordinates $22^{\circ} 01^{\prime} 07^{\prime \prime} \mathrm{S}, 54^{\circ} 32^{\prime} 15^{\prime \prime} \mathrm{W}$ and altitude of $310 \mathrm{~m}$ in the municipality of Douradina during harvest 2011/2012. The soil of the area is classified as Typic Distroferric (RH) of loamy soil. The climate, according to Köppen's humid mesothermal, Cwa type, with annual average temperatures and precipitation ranging from $20^{\circ} \mathrm{C}$ to $24^{\circ} \mathrm{C}$ and $1.250 \mathrm{~mm}$ to $1.500 \mathrm{~mm}$ (Fietz \& Fisch, 2006). For management of two experimental areas with soybean, we used the no-tillage system, and corn (Zea mays $\mathrm{L})$ as preceding crop. The area of this experiment was dried with glyphosate combined with mineral oil $\left(2.01 . \mathrm{ha}^{-1}+0.51 . \mathrm{ha}^{-1}\right)$, respectively.

The seeds of soybean cultivars were Bt L 6910 Intact RR2 PRO TM and non-Bt BMX Power RR1, constituting the two treatments in two different locations. Sowing were performed in the experimental areas first area Rincão Porã Farm, performed on 22/10/2011, second area Farm Boa Sorte performed on 29/10/2011, with a density of 15 seeds per meter, by adopting a population of approximately 300.000 plants ha ${ }^{-1}$. The row spacing was 0.50 meters. For the basic fertilizer in both cultivar used was $300 \mathrm{~kg} \mathrm{ha}^{-1}$ of NPK (02:18:18). Held control weeds and diseases with application of herbicides and fungicides.

For the evaluation of chlorophyll content in soybean leaves was used chlorophyll (SPAD-502), avoiding measures on midrib, which was collected at random positions in the upper third (TS), middle third (TM) and thirds lower (TI) in two plants per plot. 
The evaluations of both experimental areas and in two soybean cultivars were performed at 7, 14, 21, 28, 35, 42, 49, $56,63,70$ days after emergence (DAE).

For the evaluation of the factors of production, was held just a sampling at the end of the cycle when the plants were at the stadium R9, according to the scale proposed by Ritchie et al. (1982). The plant height was measured from the soil surface to the apex of the plant and the height of the first pod was the soil surface until its insertion with the aid of a graduated ruler. The number of pods per plant was performed by direct counting and productivity was obtained by the total mass of grains being corrected to $13 \%$ moisture.

For analysis of chlorophyll used the completely randomized design in a split plot design $(2 \times 3 \times 10)$ with four replications, the main plots consisting of the cultivars the subplots for positions in plant and subsubplots assessments on time. We used the Tukey test at 5\% probability, to test the interaction between cultivars and locations in plants in two regions, and held up the regression test for interaction between cultivars versus positions versus assessments for each region.

The experimental design for the factors of production were randomized in a factorial 2 × 2 [(two varieties (Bt and non-Bt) and two regions (Dourados and Douradina)] with four replications.

Data were subjected to analysis of variance (F test), and means were compared by Tukey test and regression at $5 \%$ probability, using the software $\operatorname{SISVAR}^{\circledR}$ (Ferreira, 2008).

\section{Results and Discussion}

Studies with soy describe interaction between chlorophyll content and stage of development, relating the lower levels of chlorophyll at the end of the cycle, this response is justified by the strong initial development of canopy leaves and those leaves much to be involved with the activity photosynthetic, after this period, there is a gradual shading the lower leaves of the canopy, with subsequent senescence associated with reduced light (Ragagnin et al., 2013; Casaroli et al., 2007).

Similar results have been reported with other species, as reported by Cancellier et al. (2013), Salgado et al. (2012) studied the content of chlorophyll, which is the difference between cultivars positions in the plant and in different environments.

Through the analysis of unfolding in the region of Dourados, observed responses of the cultivars in the middle of the assessments and positions in the plant, the Bt cultivar had the highest chlorophyll levels. Now evaluating the positions, the average ratings and cultivars found increased levels of chlorophyll in the middle third, followed by the upper third and lower, respectively, for the two regions (Table 1).

Table 1. Average number of joint analysis of cultivars and locations regarding the content of chlorophyll determined by chlorophyll meter (SPAD-502 Minolta $\left.{ }^{\circledR}\right)$ in soybean [Glicine max $\left.(\mathrm{L})\right] \mathrm{Bt}$ and non-Bt in the lower third (TS), the middle third (TM) and upper third (TI). Dourados and Douradina, MS, 2012

\begin{tabular}{|c|c|c|c|c|}
\hline \multirow{3}{*}{ Cultivate } & \multicolumn{4}{|c|}{ Dourados } \\
\hline & \multicolumn{4}{|c|}{ Position the plant } \\
\hline & Upper third & Middle third & Lower third & Means \\
\hline $\mathrm{Bt}$ & $38.00 \mathrm{Ab}$ & $41.60 \mathrm{Aa}$ & $34.31 \mathrm{Ac}$ & $37.97 \mathrm{~A}$ \\
\hline non Bt & $37.34 \mathrm{Ab}$ & $41.15 \mathrm{Aa}$ & $33.09 \mathrm{Ac}$ & $37.19 \mathrm{~B}$ \\
\hline \multirow[t]{2}{*}{ Means } & $37.66 \mathrm{~b}$ & $41.37 \quad \mathrm{a}$ & $33.70 \mathrm{c}$ & \\
\hline & \multicolumn{4}{|c|}{ Douradina } \\
\hline \multirow[t]{2}{*}{ Cultivate } & \multicolumn{4}{|c|}{ Position the plant } \\
\hline & Upper third & Middle third & Lower third & Means \\
\hline $\mathrm{Bt}$ & $36.41 \mathrm{Ab}$ & $40.44 \mathrm{Aa}$ & $33.28 \mathrm{Ac}$ & $36.71 \mathrm{~A}$ \\
\hline non $\mathrm{Bt}$ & $36.34 \mathrm{Ab}$ & $39.15 \mathrm{Aa}$ & $32.09 \mathrm{Ac}$ & $35.86 \mathrm{~A}$ \\
\hline Means & $36.38 \mathrm{~b}$ & $39.80 \quad \mathrm{a}$ & $32.67 \mathrm{c}$ & \\
\hline
\end{tabular}

Means followed by the same letters, uppercase column compares cultivars at each location and the means of the local cultivars, tiny line compares sites for each cultivar and places in the cultivar means, do not differ by Tukey test at $5 \%$ probability. 
The factors related to photosynthetic efficiency and consequently the growth and adaptability to various environments are leaf pigments such as chlorophylls, where the shade leaves have higher concentrations of chlorophyll per gram of dry matter than leaves exposed to direct sunlight, so the combination chlorophylls and accessory pigments enable plants to capture the greatest amount of photosynthetically active radiation (Engel \& Poggiani, 1991).

The interaction between cultivars versus positions for each region noted that the results are similar for Bt and non-Bt cultivars in the two regions, where the middle third showed the highest levels of chlorophyll, followed by upper and lower, respectively, with no statistical difference between the combinations of any of the varieties (Table 1).
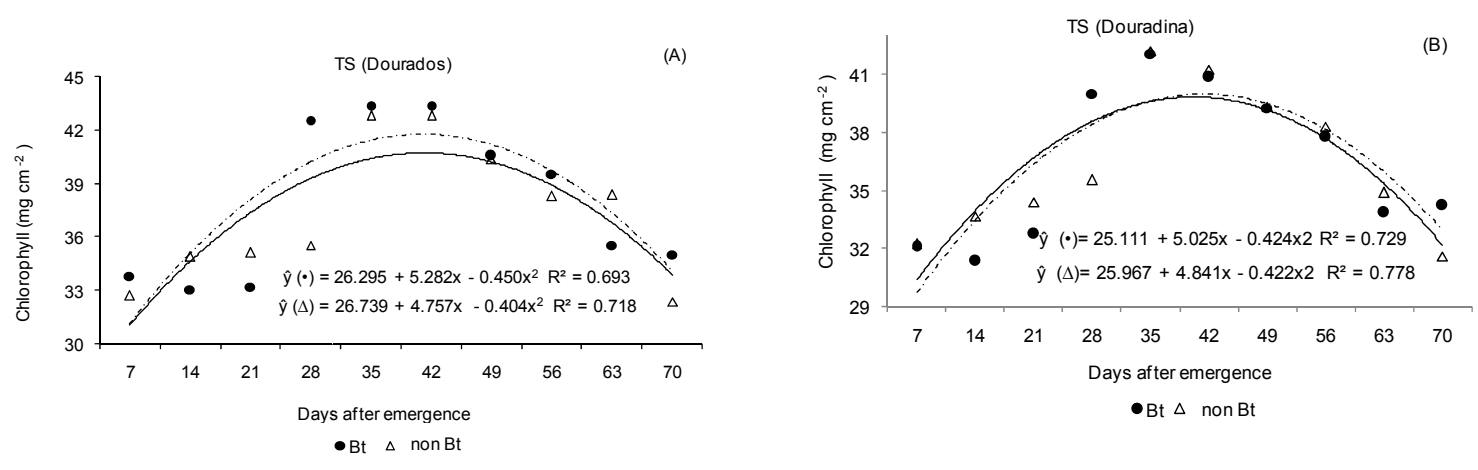

-Bt $\Delta$ non Bt
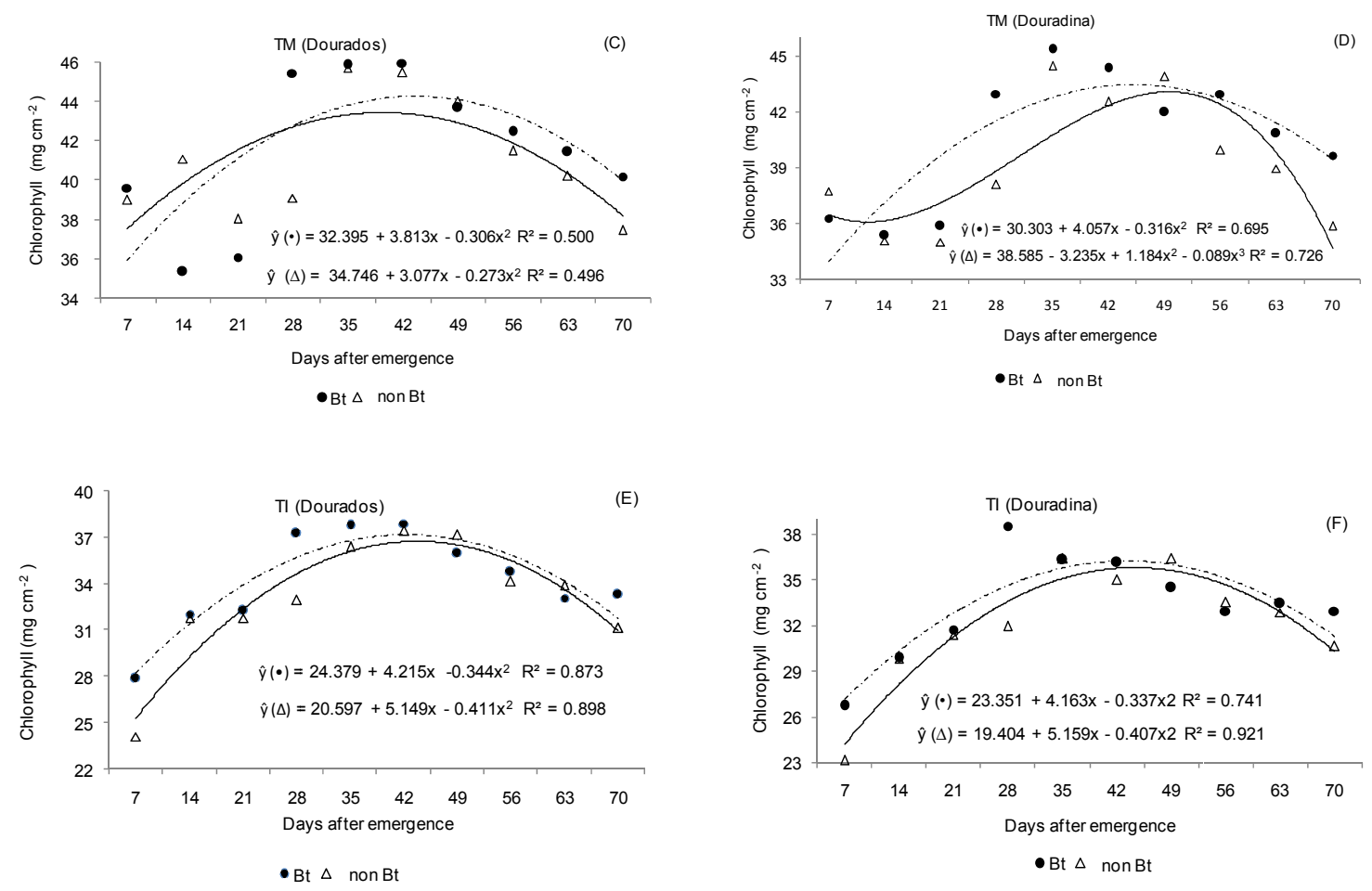

Figure 1. Regression lines fitted to the values of chlorophyll in soybean [Glycine max (L)] Bt and non-Bt in the lower third (TI), middle third (TM) and upper third (TS) as a function of days after emergence. Dourados and

Douradina, MS, 2012 
The cultivar factor can influence the chlorophyll content of the plant, as the leaves of a given cultivar tend to have certain characteristics, such as thickness, pigment content and internal structure are functions of morphological and physiological differences between cultivars, which may influence the spectral properties of the sheets (SPAD index) (Minotti et al., 1994).

The interaction of soybean cultivars with developmental stages were significant $(p<0.05)$ for chlorophyll content for all positions on the plant in the two study regions (Figure 1). Chlorophyll content in the upper leaves of the plants experienced similar behavior and Dourados, Douradina (Figures 1A and 1B), following the quadratic model to cultivate $\mathrm{Bt}$ and non-Bt. For both regions there was an increase in chlorophyll content from 7 to $42 \mathrm{DAE}$ and decreased from 42 to 70 DAE. These results were repeated assessed the lower third of the plants in Dourados and Douradina (Figure 1E and 1F).

In the middle third of the plants, only Bt soybeans grown in Douradina had the performance that followed the cubic, since soybeans do not Bt Douradina and the two cultivars Dourados followed the quadratic model (Figure 1C and 1D). It was observed that the soybean plants showed increasing values of chlorophyll until $42 \mathrm{DAE}$ and decreased from this phase continues until senescence, this confirms the fact that at the beginning of the development of culture, the plants are still small has little chlorophyll that will increase with the development and reduce again with the senescence phase.

Changes in ambient light cultivation device settings provide photosynthetic plants, which results in greater efficiency in the absorption and energy transfer to photosynthetic processes. In this context the performance of agronomic traits of soybean cultivars can vary from one environment to another culture, it is necessary that different cultivars are evaluated in different places, periods and technologies (Peluzio et al., 2012; Barbosa et al., 2011).

For the region of Dourados, the highest chlorophyll levels were presented to $42 \mathrm{DAE}$ for soybeans $\mathrm{Bt}$ and non-Bt in TS (43.38 and $42.83 \mathrm{mg} \mathrm{cm}^{-2}$ ) TI (37.90 and $\left.37.41 \mathrm{mg} \mathrm{cm}^{-2}\right)$ and TM in the highest levels were at 42 DAE for biotech soybean $\left(45.94 \mathrm{mg} \mathrm{cm}^{-2}\right)$ and $35 \mathrm{DAE}$ to grow non-Bt $\left(45.70 \mathrm{mg} \mathrm{cm}^{-2}\right)$. In Douradina higher content of chlorophyll was for biotech soybean at 28 DAE $\left(38.50 \mathrm{mg} \mathrm{cm}^{-2}\right)$ and non-Bt to 49 DAE $\left(36.40 \mathrm{mg} \mathrm{cm}^{-2}\right)$ in the lower third. For TM and TS cultivating Bt was maximum levels at 35 DAE (45.35 and $42.09 \mathrm{mg} \mathrm{cm}^{-2}$ ) and for non Bt 35 DAE (44.46 and $42.22 \mathrm{mg} \mathrm{cm}^{-2}$ ) (Figure 1).

Board and Modali (2005) point out that the accumulation of dry matter from the reproductive stage is a major component to estimate the productivity of soybean, mainly due to higher solar radiation interception and carbon partitioning to the reproductive organs, which assists in optimizing productivity.

Regarding the chlorophyll content of the plant in different thirds found that the upper and middle third of the sheet have higher levels of this pigment, which expresses superiority to the lower third of the leaf. Possibly this fact is connected with the higher concentration of pigment in the fully formed and new leaves (Taiz \& Zeiger, 2008). Similar results were observed by other authors to analyze the loss of green color on the old leaves senescer in temperature and humidity and hence the intense chlorophyll degradation until complete yellowing of leaves (Hung \& Kao, 1997; Thimann et al., 1982).

Chlorophyll levels in the lower thirds of the plant tend to be less pronounced, because they suffer interference of the architecture and the arrangement of the leaf canopy, causing the overlapping leaf and can shading (Gil et al., 2002).

Although the productive capacity of a plant depends essentially on their genetic constitution, the externalization of such agronomic trait is subject to the conditions of the environment in which it finds itself (Rocha et al., 2012; Amorim et al., 2011).

In this context it was noted that for plant height had higher values for both cultivars in the region of gold, however, when comparing cultivars, soybean did not differ from non-Bt, Bt in Dourados and was superior in Douradina, respectively (Table 2). But the two cultivars in the two regions had superior height to $50 \mathrm{~cm}$ suitable for the culture as a criterion for the selection of new cultivars (Amorim et al., 2011).

Sediyama (2009) found that soybean morphological features variables to cultivate and may be influenced by the environment such as plant height, ranging from 30 to $200 \mathrm{~cm}$.

For the variable height of the first pod were significantly different among cultivars and locations in which to cultivate Bt was presented the greatest height of insertion for the two regions, but they all had values sufficient for performing mechanical harvesting. It was also observed that the Bt cultivar had the highest height of the first pod in Douradina while cultivating non Bt had similar results in the two regions (Table 2). 
According to Sediyama et al., (2005), so there is no loss at harvest by cutting bar, the minimum height of the first pod should be 10 to $12 \mathrm{~cm}$ in soils of flat topography. Under the conditions of the experiment would have no problems growing crop losses in flatter topography, since all had height of the first pod of more than $10 \mathrm{~cm}$.

In the region of Dourados, the number of pods per plant for Bt and non-Bt cultivars had higher number compared with the region Douradina. Analyzing each region independently revealed that the two regions for soybean $\mathrm{Bt}$ was better than the non-Bt number of pods (Table 2).

Production components stand out from the, number of pods per plant and the character that contributes to grain yield in legumes, since it presents the highest correlations with production (Almeida et al., 2011; Pinchinat \& Adams 1966). Generally, most of the gains in production resulting from increases in the total number of pods per plant, especially when higher yields are obtained (Mauad et al., 2010).

Table 2. Average number of plant height (PH), first pod height (APV), number of pods per plant (NPP) and yield $\left(\mathrm{kg} \mathrm{ha}^{-1}\right)$ soy Bt and non Bt. Dourados and Douradina, MS, 2012

\begin{tabular}{|c|c|c|c|c|c|c|}
\hline \multirow{3}{*}{ Cultivate } & \multicolumn{3}{|c|}{$\begin{array}{l}\text { Height of plant } \\
(\mathrm{cm})\end{array}$} & \multicolumn{3}{|c|}{$\begin{array}{l}\text { Height of plant } \\
(\mathrm{cm})\end{array}$} \\
\hline & \multicolumn{2}{|c|}{ Locations } & \multirow[b]{2}{*}{ Means } & \multicolumn{2}{|c|}{ Locations } & \multirow[b]{2}{*}{ Means } \\
\hline & Dourados & Douradina & & Dourados & Douradina & \\
\hline \multirow{3}{*}{$\begin{array}{c}\text { Bt } \\
\text { non Bt } \\
\text { Means }\end{array}$} & $89.80 \mathrm{Aa}$ & $78.20 \mathrm{Ab}$ & \multirow{3}{*}{$\begin{array}{l}84.00 \mathrm{~A} \\
73.00 \mathrm{~B}\end{array}$} & $23.60 \mathrm{Ab}$ & $28.80 \mathrm{Aa}$ & $26.20 \mathrm{~A}$ \\
\hline & $91.40 \mathrm{Aa}$ & $54.60 \mathrm{Bb}$ & & $14.80 \mathrm{Ba}$ & $11.40 \mathrm{Ba}$ & \multirow[t]{2}{*}{$13.10 \mathrm{~B}$} \\
\hline & 90.60 a & $66.40 \mathrm{~b}$ & & $19.20 \mathrm{a}$ & $20.10 \quad a$ & \\
\hline \multirow{3}{*}{ Cultivate } & \multicolumn{3}{|c|}{$\begin{array}{c}\text { Number of pods per plant } \\
\text { (unit) }\end{array}$} & \multicolumn{3}{|c|}{$\begin{array}{c}\text { Productivity } \\
\left(\mathrm{kg} \mathrm{ha}^{-1}\right)\end{array}$} \\
\hline & \multicolumn{2}{|c|}{ Locations } & & \multicolumn{2}{|c|}{ Locations } & \\
\hline & Dourados & Douradina & Means & Dourados & Douradina & Means \\
\hline \multirow{3}{*}{$\begin{array}{c}\text { Bt } \\
\text { non Bt } \\
\text { Means }\end{array}$} & $588.20 \mathrm{Aa}$ & $290.80 \mathrm{Ab}$ & $439.50 \mathrm{~A}$ & $3276.52 \mathrm{Aa}$ & $1212.66 \mathrm{Ab}$ & \multirow{3}{*}{$\begin{array}{l}2244.59 \mathrm{~A} \\
1712.29 \mathrm{~B}\end{array}$} \\
\hline & $476.40 \mathrm{Ba}$ & $165.80 \mathrm{Bb}$ & $321.10 \mathrm{~B}$ & $2576.83 \mathrm{Ba}$ & $847.75 \mathrm{Bb}$ & \\
\hline & $532.30 \quad \mathrm{a}$ & $228.30 \mathrm{~b}$ & & $2926.67 \quad a$ & $1030.20 \quad b$ & \\
\hline
\end{tabular}

Means followed by the same letters, uppercase column compares cultivars at each location and the means of the local cultivars, tiny line compares sites for each cultivar and places in the cultivar means, do not differ by Tukey test at $5 \%$ probability.

Given the existence of the interaction cultivar versus environments, continuous assessments are required in network trials in order to determine the agronomic behavior of genotypes and their adaptation to different local conditions (Porto et al., 2007).

One of the main tools for farmers to increase productivity and stability in production was the use of new soybean varieties. However, knowing the adaptability and stability of genotypes is essential to mitigate the effects of genotype versus environment and facilitate the recommendation of cultivars (Lima et al., 2008).

In this context it was found that there was a difference in productivity between the varieties in the two regions, soybean Bt values greater than the non-Bt. Dourados in the Bt and non-Bt cultivars had higher yields than in the region Douradina. These results confirm the work of Lemos et al. (2011), Avila et al. (2007) and Garcia et al. (2007) showed that the productivity of soybeans vary between cultivation sites, due to the effect of environmental factors.

\section{Conclusion}

From the results obtained, it can be concluded that the Bt technology did not influence the chlorophyll content of soybean, the two cultivars showed similar levels, with higher concentrations in the middle third of the plants in the two regions studied.

For the region of Dourados, the highest chlorophyll levels were presented to $42 \mathrm{DAE}$ for soybeans $\mathrm{Bt}$ and non-Bt in TS (43.38 and $\left.42.83 \mathrm{mg} \mathrm{cm}^{-2}\right)$ TI ( 37.90 and $\left.37.41 \mathrm{mg} \mathrm{cm}^{-2}\right)$ and TM in the highest levels were at 42 DAE for biotech soybean $\left(45.94 \mathrm{mg} \mathrm{cm}^{-2}\right)$ and $35 \mathrm{DAE}$ to grow non-Bt $\left(45.70 \mathrm{mg} \mathrm{cm}^{-2}\right)$. In Douradina higher content of chlorophyll was for biotech soybean at 28 DAE $\left(38.50 \mathrm{mg} \mathrm{cm}^{-2}\right)$ and non-Bt to $\left.49 \mathrm{DAE} 36.40 \mathrm{mg} \mathrm{cm}^{-2}\right)$ in the 
lower third. For TM and TS cultivating Bt was maximum levels at 35 DAE (45.35 and $42.09 \mathrm{mg} \mathrm{cm}^{-2}$ ) and for non Bt 35 DAE (44.46 and $42.22 \mathrm{mg} \mathrm{cm}^{-2}$ ).

For agronomic attributes, plant height, first pod height, number of pods per plant and yield Bt soybeans had higher values compared to non-Bt soybeans in two environmental studies.

\section{References}

Almeida, R. D., Peluzio, J. M., \& Afferri, F. S. (2011). Divergência genética entre cultivares de soja, sob condições de várzea. Revista Ciência Agronômica, http://dx.doi.org/101590/S1806-66902011000100014

Amorim, F. A., Hamawaki, O. T., Sousa, L. B., Lana, R. M. Q., \& Hamawaki, C. D. L. (2011). Época de semeadura no Potencial produtivo de Soja em Uberlândia-MG. Semina. Ciências Agrárias, 32(1), 1793-1802. http://dx.doi.org/10.5433/1679-0359.2011v32Suplp1793

Antunes, J. F. G., Mercante, E., Esquerdo, J. C. D. M., Lamparelli, R. A. C., \& Rocha, J. V. (2012). Estimativa de área de soja por classificação de imagens normalizada pela matriz de erros. Pesquisa Agropecuária Brasileira, 47(9), 1288-1294. http://dx.doi.org/101590/S0100-204X2012000900014

Araújo, S. A. C., Vasquez, H. M., Torres Neto, A., Campostrini, E., Deminicis, B. B., \& Lima, É. S. (2013). Indirect method for quantifying the content of photosynthetic pigments in genotypes of dwarf elephant grass. Acta Scientiarum. Zootechny, 35(1), 43-47. doi: 10.4025/actascianimsci.v35i1.15178

Argenta, G., Silva, P. R. F., Bortolini, C. G., Forsthofer, E. L., \& Strieder, M. L. (2001). Relação da leitura do clorofilômetro com os teores de clorofila extraível e de nitrogênio na folha de milho. Revista Brasileira de Fisiologia Vegetal, 13(2), 158-167. http://dx.doi.org/10.1590/S0103-31312001000200005

Arnon, D. I. (1949). Copper enzymes in isolated chloroplasts. Polyphenoloxidase in Beta vulgaris. Plant Physiology, 24(1), 1-15.

Ávila, M. R., Braccini, A. L., Scapim, C. A., Mandarino, J. M. G., Albrecht, L. P., \& Vidigal Filho, P. S. (2007). Componentes do rendimento, teores de isoflavonas, proteínas, óleo e qualidade de sementes de soja. Revista Brasileira de Sementes, 29(3), 111-127.

Barros, R., \& Degrande, P. E. (2012). Desempenho do algodão-Bt como tática de controle de pragas em condições de campo. Cientifica, 40(2), 117-137.

Barbosa, V. S., Peluzio, J. M., Afferri, F. S., \& Siqueira, G. B. (2011). Comportamento de cultivares de soja, em diferentes épocas de semeaduras, visando à produção de biocombustivel. Revista Ciência Agronômica, 42(3), 742-743. http://dx.doi.org/10.1590/S1806-66902011000300021

Board, J. E., \& Modali, H. (2005). Dry matter accumulation predictors for optimal yield in soybean. Crop Science, 45(5), 1790-1799. http://dx.doi.org/10.2135/cropsci2004.0602

Cancellier, E. L., Silva, J., Santos, M. M., Siebenechler, S. C., \& Fidelis, R. R. (2013). Índices de clorofila em partes da planta de arroz de terras altas. Revista Verde de Agroecologia e Desenvolvimento Sustentável, 8(1), 199-206.

Casaroli, D., Fagan, E. B., Simon, J., Medeiros, S. L. P., Manfron, P. A., Dourado Neto, D., ... Martin, T. N. (2007). Radiação solar e aspectos fisiológicos na cultura de soja. Revista da Faculdade de Zootecnia, Veterinária e Agronomia, 14(2), 102-120.

Dutra, C. C., Koch, R. L., Burkness, E., Meissle, M., Romeis, J., Hutchison, W. D., \& Fernandes, M. G. (2012). Harmonia axyridis (Pallas) (Coleoptera: Coccinellidae) exhibits no preference between Bt and non-Bt maize fed Spodoptera frugiperda (JE Smith) (Lepidoptera: Noctuidae). Plos One, 7(9), e44867. http://dx.doi.org/10.1371/journal.pone.0044867

Engel, V. L., \& Poggiani, F. (1991). Estudo da concentração de clorofila nas folhas e seu espectro de absorção de luz em função do sombreamento em mudas de quatro espécies florestais nativas. Revista Brasileira de Fisiologia Vegetal, 3(1), 39-45.

Ferreira, D. F. (2008). Sisvar: um programa para análises e ensino de estatística. Revista Symposium, 6(1), 36-41.

Fietz C. R., \& Fisch G. F. (2006). O clima da região de Dourados, MS. Dourados, MS, Brasil: Embrapa Agropecuária Oeste, (1 edn, p. 32). 
Fonseca, P. R. B., Fernades, M. G., Dutra, F., Souza, T. A., \& Pontim, B. C. A. (2012). Uso do SPAD-502 na avaliação dos teores foliares de clorofila, em híbridos de milho, (Zea mays L.) Bt e isogênico. Revista Verde de Agroecologia e Desenvolvimento Sustentável, 7(1), 56-60.

Garcia, A., Pípolo, A. E., Lopes, I. O. N., \& Portugal, F. A. F. (2007). Instalação da lavoura de soja: época, cultivares, espaçamento e população de plantas. Londrina: Embrapa Soja, (1 edn, p. 11). (Circular Técnica, 51).

Gil, P. T., Fontes, P. C. R., Cecon, P. R., \& Ferreira, F. A. (2002). Índice SPAD para o diagnóstico do estado de nitrogênio e para o prognóstico da produtividade da batata. Horticultura Brasileira, 20(4), 611-615.

Guimarães, T. G., Fontes, P. C. R., Pereira, P. R. G., Alvarez, V. H., \& Monnerat, P. H. (1999). Teores de clorofila determinados por medidor portátil e sua relação com formas de nitrogênio em folhas de tomateiro cultivados em dois tipos de solo. Bragantia, 58(1), 209-216. http://dx.doi.org/10.1590/S0006-87051999000100020

Homrich, M. S., Passaglia, L. M. P., Pereira, J. F., Bertagnolli, P. F., Pasquali, G., Zaidi, M. A., ... Zanettini, M. H. B. (2008). Resistance to Anticarsia gemmatalis Hübner (Lepidoptera, Noctuidae) in transgenic soybean (Glycine max (L.) Merrill Fabales, Fabaceae) cultivar IAS5 expressing a modified Cry1Ac endotoxin. Genetics and Molecular Biology, 31(2), 522-531. http://dx.doi.org/10.1590/S1415-47572008000300020

Hung, K. T., \& Kao C. H. (1997). Lipid peroxidation in relation to senescence of maize leaves. Journal of Plant Physiology, 150(3), 283-286. http://dx.doi.org/10.1016/S0176-1617(97)80121-6

Kramer, T., \& Koslowski, T. (1979). Physiology of Woody Plants. (1 edn, p. 811). New York: Academic Press.

Lemos, L. B., Farinelli, R., Cavariani, C., \& Zapparoli, R. A. (2011). Desempenho agronômico e produtivo de cultivares de soja em diferentes safras. Cientifica, 39(1/2), 44-51.

Lima, W. F., Pípolo, A. E., Moreira, J. U. B., Carvalho, C. G. P., Prete, C. E. C., Arias, C. A. A., ... Toledo, J. F. F. (2008). Interação genótipo-ambiente de soja convencional e transgênica resistente a glifosato, no Estado do Paraná. Pesquisa Agropecuária Brasileira, 43(6), 195-201.

Mauad, M., Silva, T. L. B., Neto, A. I. A., \& Abreu, V. G. (2010). Influência da densidade de semeadura sobre características agronômicas na cultura da soja. Agrarian, 3(9), 175-181.

Minolta, C. (1989). Manual for chlorophyll meter SPAD 502. (1 edn, p. 22). Osaka: Minolta, Radiometric Instruments Divisions.

Minotti, P. L., Halseth, D. E., \& Sieczka, J. B. (1994). Field chlorophyll measurements to assess the nitrogen status of potato varieties. HortScience, 29(12), 1497-1500.

Neves, J. A., Silva, J. A. L., Barbosa, D. R. S., Sediyama, T., Teixeira, R. C., \& Rocha, R. S. (2013). Agronomic performance of soybean genotypes in low latitude in Teresina-PI, Brazil. Journal of Agricultural Science, 5(3), 243-253. http://dx.doi.org/10.5539/jas.v5n3p243

Peluzio, J. M., Afférri, F. S., Monteiro, F. J. F., Vaz de Melo, A., \& Pimenta, R. S. (2010). Adaptabilidade e estabilidade de cultivares de soja em várzea irrigada no Tocantins. Revista Ciência Agronômica, 41(3), 427-434. http://dx.doi.org/10.1590/S1806-66902010000300015

Peluzio, J. M., Pires, L. P. M., Cancellier, L. L., Afférri, F. S., Colombo, G. A., Teixeira Júnior, T., \& Ribeiro, G. R. S. (2012). Genetic divergence among soybean cultivars in irrigated lowland in the State of Tocantins. Ciência Rural, 42(3), 1-6. http://dx.doi.org/10.1590/S0103-84782012000300002

Pereira, R. G., Albuquerque, A. W., Souza, R. O., Silva, A. D., Santos, J. P. A., Barros, E. S., \& Medeiros, P. V. Q. (2011). Sistemas de manejo do solo: soja [Glycine max (L.)] consorciada com Brachiaria decumbens (STAPF). Pesquisa Agropecuária Tropical, 41(1), 44-51.

Pinchinat, A. M., \& Adams, M. W. (1966). Yield Components in beans, as affected by intercrossing and neutron irradiation. Turrialba, 16(3), 247- 252.

Porto, W. S., Carvalho, C. G. P., \& Pinto, R. J. B. (2007). Adaptabilidade e estabilidade como critérios para seleção de genótipos de girassol. Pesquisa Agropecuária Brasileira, 42(4), 491-499. http://dx.doi.org/10.1590/S0100-204X2007000400006

Ragagnin, V. A., Sena Jr, D. G., Dias, D. S., Braga, W. F., \& Nogueira, P. D. M. (2013). Growth and nodulation of soybean plants fertilized with poultry litter. Ciência e Agrotecnologia, 37(1), 17-24. http://dx.doi.org/10.1590/S1413-70542013000100002 
Richardson, A. D., Duigan, S. P., \& Berlyn, G. P. (2002). An evaluation of noninvasive methods to estimate foliar chlorophyll content. New Phytologist, 153(1), 185-194. http://dx.doi.org/10.1046/j.0028-646X.2001.00289.x

Ritchie, S., Hanway, J. J., \& Thompson, H. E. (1982). How a soybean plant develops. Ames: Iowa State University of Science and Technology, Cooperative Extension Service, (1 edn) (p. 20). (Special report, 53).

Rocha, R. S., Silva, J. A. L., Neves, J. A., Sediyama, T., \& Teixeira, R. C. (2012). Desempenho agronômico de variedades e linhagens de soja em condições de baixa latitude em Teresina-PI. Revista Ciência Agronômica, 43(1), 154-162.

Salgado, F. H. M., Silva, J., Oliveira, T. C., Barros, H. B., Passos, N. G., \& Fidelis, R. R. (2012). Eficiência de genótipos de feijoeiro em resposta à adubação nitrogenada. Pesquisa Agropecuária Tropical, 42(4), 368-374.

Sediyama, T. 2009. Tecnologias de produção e usos da soja. (1 edn, p. 314), Londrina, PR: Mecenas.

Sediyama, T., Teixeira, R. C., \& Reis, M. S. (2005). Melhoramento da Soja. In: Borém, A. Melhoramento de espécies cultivadas. (1 edn, p. 604), Viçosa: UFV.

Souza, G. S., Castro, E. M., Soares, A. M., Santos, A. R., \& Alves, E. (2011). Teores de pigmentos fotossintéticos, taxa de fotossíntese e estrutura de cloroplastos de plantas jovens de Mikania laevigata Schultz Bip. ex Baker cultivadas sob malhas coloridas. Semina. Ciências Agrárias, 32(1), 1843-1854. http://dx.doi.org/10.5433/1679-0359.2011v32Suplp1843

Taiz, L., \& Zeiger, E. (2008). Fisiologia Vegetal. (4 edn, p. 819). Porto Alegre: Artmed.

Thimann, K. V., Satler, S. O., \& Trippi, V. (1982). Further extension of the syndrome of leaf senescence. In: Plant growth substances. (1 edn, p. 683). London: Academic Press.

Uddling, J., Gelang-Alfredsson, J., Piikki, K., \& Pleijel, H. (2007). Evaluating the relationship between leaf chlorophyll concentration and SPAD-502 chlorophyll meter readings. Photosynth. Research, 91(1), 37-46. http://dx.doi.org/10.1007/s11120-006-9077-5

Yin, Z., Plader, W. E., \& Malepszy, S. (2004). Transgene inheritance in plants. Journal of Applied Genetics, 45(2), 127-144.

Yu, H. L., Yun, H. L., \& Kong, M. W. (2011). Risk assessment and ecological effects of transgenic Bacillus thuringiensis crops on non-target organisms. Journal of Integrative Plant Biology, 53(7) 520-538. http://dx.doi.org/10.1111/j.1744-7909.2011.01047.x

Yuan, L., \& Knauf, V. C. (1997). Modification of plants components. Current Opinion in Biotechnology, 8(2), 227-233.

\section{Copyrights}

Copyright for this article is retained by the author(s), with first publication rights granted to the journal.

This is an open-access article distributed under the terms and conditions of the Creative Commons Attribution license (http://creativecommons.org/licenses/by/3.0/). 